\section{Molecular genetic basis of primary inherited optic neuropathies}

M Votruba

\begin{abstract}
Aim To review the molecular genetic basis of primary inherited optic neuropathies.

Methods Medline and Embase search.

Results Inherited optic neuropathies are a genetically diverse group of disorders that present with reduced visual acuity and the clinical appearance of optic atrophy. The inherited optic neuropathies may be sporadic or familial, in which case the mode of inheritance may be Mendelian (autosomal dominant, autosomal recessive, $\mathrm{X}$-linked recessive) or non-Mendelian (mitochondrial). Two genes for dominantly inherited optic atrophy have been mapped (OPA1 and OPA4), of which the gene has been identified in one (OPA1). A gene for recessive optic atrophy (OPA3) has also been identified. X-linked optic atrophy (OPA2) has been mapped but to date no gene has been identified. Mutations in mitochondrial DNA have been identified in Leber's hereditary optic neuropathy.

Conclusions Mutations in genes from both the nuclear and mitochondrial genomes appear to be responsible. Mitochondrial dysfunction, in the broadest sense, is emerging as central to the pathogenesis of this group of conditions.
\end{abstract}

School of Optometry and Vision Sciences Cardiff University

Cardiff, UK

Correspondence: M Votruba Molecular and Cell Biology Group

School of Optometry and

Vision Sciences

Cardiff University

Redwood Building King

Edward VII Avenue Cardiff CF10 3ND, UK

Tel: + 442920870134

Fax: +4402920874859

E-mail: votrubam@

cardiff.ac.uk

Received: 4 September 2003

Accepted: 4 September 2003

Presented in part at the XXXIII Cambridge Ophthalmological Symposium, Cambridge, UK, September, 2003:

'The optic nerve'.
Eye (2004) 18, 1126-1132. doi:10.1038/sj.eye.6701570

Keywords: inherited optic neuropathy; Leber hereditary optic neuropathy (LHON): retinal ganglion cell (RGC) OPA1

\section{Introduction}

The inherited optic neuropathies comprise a group of disorders in which there is cell death confined to the retinal ganglion cells. The primary hereditary optic neuropathies comprise autosomal dominant, autosomal recessive and $\mathrm{X}$-linked recessive optic atrophy, and the maternally inherited Leber's hereditary optic neuropathy. The optic atrophy seen in some forms of glaucoma may be an inherited optic neuropathy and appears to have a genetic basis, at least in part. ${ }^{1,2}$ The main clinical features of optic neuropathies are summarized in this volume by Newman et al. Ganglion cell loss in the hereditary optic neuropathies leads to central visual loss, dyschromatopsia and central visual field defects, with the papillomacular bundle preferentially affected. The visual loss is bilateral, symmetrical, and irreversible once ganglion cell death has occurred. The visual loss is usually gradual with the exception of Leber's hereditary optic neuropathy, where visual loss is sudden and severe and occurs asynchronously in the two eyes. ${ }^{3}$ In keeping with a conduction deficit, visually evoked responses are delayed, the amplitude is reduced, the flash electroretinogram (ERG) is normal but the pattern ERG shows an N95 component reduction, a feature of typical of ganglion cell dysfunction. ${ }^{4}$

\section{Leber's hereditary optic neuropathy}

Leber's hereditary optic neuropathy (LHON) is transmitted by non-Mendelian, mitochondrial inheritance and is due to mutations in mitochondrial DNA. As mitochondria are maternally inherited ${ }^{5}$ there is no male to male transmission in an LHON pedigree. Human mitochondrial DNA (mtDNA) is a closed, circular molecule of 16569 base pairs. There are thousands of copies per cell and they segregate randomly at meiosis and mitosis. ${ }^{6}$ Each cell can contain different proportions of both wild type and mutant mtDNA. With multiple cell divisions the population of mtDNA in a cell can drift towards either pure mutant or wild type (homoplasmy) or stay mixed (heteroplasmy). This may be important, as the magnitude of a defect in oxidative phosphorylation (OXPHOS) 
can relate to the proportion of mutant mtDNA. The mitochondrial genome is essential for aerobic metabolism, as it encodes 37 of the genes in the OXPHOS system and 13 of the protein subunits. Complexes I-V reside in the mitochondrial inner membrane. The vast majority of cellular adenosine triphosphate (ATP) is generated by this system as complexes I to IV are key components of the electron transport chain. This chain generates an electrochemical gradient across the mitochondrial inner membrane, which is used by complex $\mathrm{V}$ to synthesize ATP. The retina, optic nerve, and extra-ocular muscles are among the most ATP-dependent tissues in the body although each body tissue has different OXPHOS requirements. There are broader ophthalmic manifestations of mtDNA abnormalities including optic neuropathy, pigmentary retinopathy, ophthalmoplegia, and ptosis, but LHON appears to be the most prevalent mitochondrial genetic disorder. ${ }^{7}$

Three primary mtDNA mutations account for $95 \%$ of LHON cases in populations of European descent. These mutations are G3460A (13\% of cases), G11778A (69\%) and T14484C (14\%), ${ }^{8}$ and they are homoplasmic in the large majority of families. Mutations at np $11778,{ }^{9} 3460,{ }^{10}$ and $14484,{ }^{11,12}$ are 'primary', as the identification of one of these pathogenic mutations establishes the diagnosis even in the absence of a family history. Mutations at $\mathrm{np}$ 3460 and 14484 produce A52 T and M64 V substitutions in the NADH dehydrogenase (ND) 1 and ND6 subunits of complex I, respectively, and mutation at 11778 produces an $\mathrm{R} 340 \mathrm{H}$ substitution in the respiratory chain complex I subunit ND4. Other rare primary mutations, including T14596A, C14498T, G13730A, G14459A, C14482G, and A14495G have been identified. ${ }^{13-15}$ LHON shows variable penetrance and a primary mtDNA mutation is essential but not sufficient to manifest optic neuropathy. So-called 'secondary' mutations may also be involved in the pathogenesis of $\mathrm{LHOH}$ but these also occur at a lower prevalence in control populations, where they may represent polymorphisms. The secondary mutations usually occur in association with a primary mutation or other secondary mutations if implicated in LHON. They generally cause the mutation of a less highly conserved amino acid. Secondary pathogenic mutations include np G13708A, G15812A, A4917G, T4216C, G9804A, G9438A, and G15257A. ${ }^{16-18}$

The role of the European haplotype J (G15812A, G15257A, G13708A, and T4216C) in disease expression is still unclear. ${ }^{19}$ In particular, approximately $75 \%$ of patients with the 14484 mutation have this haplotype, while it is only found in $\sim 10 \%$ of mtDNAs from the general European population. It may be that having a polymorphism within the haplotype $J$ increases the penetrance of the 14484 mutation. It is not clear why men are clinically affected more often than women. The estimated male to female ratio is between $3: 1$ and $5.6: 1$, and up to $80-90 \%$ of cases in some series are male. ${ }^{20}$ The suggestion that an X-linked factor predisposes to disease ${ }^{21}$ has received little support in the literature and has been questioned by a re-evaluation of the original data, $^{22}$ leaving many unanswered questions. A given LHON family will have one primary mutation and may harbour several secondary mutations. A nuclear modifier, such as a functional polymorphism in a tissuespecific protein, could be involved in the variable penetrance seen. However, there are a few well-defined families in which a primary mutation has not yet been found. There are also four reported families that carry two primary mutations: that is, the 11778 and 14484 mutations. ${ }^{23}$

\section{Genotype and phenotype}

The clinical differences in the optic neuropathy seen as a result of the three primary mutations are subtle. The only real distinguishing feature appears to be in the spontaneous recovery of acuity. The T14484C mutation is associated with the best visual outcome $(6 / 24$ or better in $71 \%$ of patients). ${ }^{12,24,25}$ In all, $50 \%$ of reported patients with the $\mathrm{T} 14484 \mathrm{C}$ mutation have some recovery of vision. A younger age of onset of visual loss with this mutation and other mutations is also associated with a better visual outcome, especially if the onset is before the age of 20 years. ${ }^{26}$ Visual recovery can occur more than a year later. If visual acuity improves it does not deteriorate again. Mutations at G11778A and G3460A appear to be associated with a similar visual outcome (1/60 to 3/60), but mutation at np 11778 is particularly severe in onethird of female patients. ${ }^{27}$ Mutation load may be significant in the $\sim 15 \%$ of LHON patients in whom the mtDNA is heteroplasmic. Males with less than $60 \%$ load of 11778 mutation in peripheral blood have a lower risk of visual loss. ${ }^{28}$

\section{Pathophysiology of LHON}

Since the identification of the first mtDNA mutation in LHON in $1988^{9}$ over 15 years of research have yet to give us a full understanding of the pathogenesis of visual loss. Histopathology from LHON patients with long-standing visual loss shows axonal degeneration in the optic nerve and loss of myelin, and there is evidence that the small axons of the papillomacular bundle, found centrally in the optic nerve, are particularly vulnerable. ${ }^{29,30}$ The respiratory dysfunction may lead to axoplasmic stasis and swelling, with evidence of demyelination. This may be reversible, as evidenced by the possibility of recovery of vision, but if the mitochondrial apoptotic pathway is 
activated, as it is most likely, ${ }^{31}$ ganglion cells are permanently lost.

The relatively high prevalence of tobacco and alcohol consumption in affected individuals, reported by some authors, ${ }^{26}$ may suggest a clinical interaction between the reduction in ATP generating capacity caused by the mutations that lead to complex I dysfunction and environmental factors. There is however, mounting evidence that the optic neuropathy in LHON is not a simple result of decreased complex I activity in mitochondrial electron transfer. ${ }^{32}$ Analysis of in vitro lymphoblastoid lines from LHON patients and transmitochondrial cybrid lines into which the 3460 , 11778,14484 , or 14459 mutations were introduced, does not show a convincing correlation between mutation and complex I activity. ${ }^{32}$ The equivalent in vivo work, using $31 \mathrm{P}$ magnetic resonance spectroscopy to assess energy metabolism in skeletal muscle of LHON patients, has also failed to show convincing reduction in bioenergetic function in muscle, ${ }^{33}$ although a marked defect in brain has been observed. ${ }^{34}$ However, LHON mutations may increase mitochondrial reactive oxygen species and this could lead to oxidative stress and the trigger for retinal ganglion cell dysfunction and apoptosis. This may be particularly important in neural cells. ${ }^{35}$

\section{Autosomal dominant optic atrophy}

Dominantly inherited optic atrophy (ADOA), also known as Kjer's optic atrophy, is the most common isolated optic neuropathy. A gene for dominant optic atrophy mapping to chromosome $3 \mathrm{q} 28$-qter, $O P A 1^{36}$ has been identified. ${ }^{37,38}$ A large number of families have been reported to map to the locus on chromosome 3q28-qter, suggesting that it may be the predominant locus. A second dominant optic atrophy locus (OPA4) has been mapped in one pedigree to chromosome 18q12.2-q12, ${ }^{39}$ although the gene has not been identified to date. The available evidence suggests that the phenotype of OPA4 may be similar to OPA1.

\section{The OPA1 gene}

The OPA1 gene is 6031 nucleotides long and is composed of 31 exons spanning $>114 \mathrm{~kb}$ of genomic DNA. It encodes a mitochondrial dynamin-related GTP protein of 960 amino acids. The OPA1 gene is ubiquitously expressed with most abundant expression in retina and brain. ${ }^{37,38}$ OPA1 is widely expressed in many regions of mouse brain. ${ }^{40}$ Two additional exons, $4 \mathrm{~b}$ and $5 \mathrm{~b}$, generate eight isoforms by alternative splicing, and two of these splice variants are particularly highly expressed in fetal brain, retina, and heart. ${ }^{41}$
There is a wide spectrum of mutations throughout the gene, with over 70 reported to date..$^{37,38,41-46}$ There is a concentration of mutations in the GTPase and dynamin central region (coded for by exons 8 to 28), but to date no mutations have been found in exons $4,4 b$, and $5 b$, which are alternately spliced. Since the majority of mutations result in protein truncation, and most mutations probably represent null alleles, dominant inheritance of the disease may result from haploinsufficiency of OPA1. A $560-860 \mathrm{~kb}$ microdeletion on chromosonme $3 \mathrm{q} 28$ that results in the complete loss of one copy of the OPA1 gene has been reported. ${ }^{47}$ Missense mutations may cause disease by a dominant-negative mechanism. One family has been reported showing semi-dominance, ${ }^{43}$ with heterozygous mutations in OPA1. The estimated penetrance figure of $98 \%$ in dominant optic atrophy has been revised downwards recently in the light of molecular studies showing that penetrance may vary from family to family and mutation to mutation. Penetrance has been reported as high as $100 \%$ (IVS12 $+1 \mathrm{~g}>\mathrm{t}$ mutation resulting in exon 12 skipping ${ }^{46}$ ) and as low as $43 \%$ (2708del(TTAG) mutation in exon $27^{42}$ ).

\section{OPA1 protein and mitochondria}

The OPA1 protein is a dynamon-related GTPase, comprising a highly basic amino-terminal that forms a mitochondrial targeting sequence, a dynamin-GTPase domain, and a C-terminus of unknown function. The C-terminus of OPA1 differs from other dynamin family members in lacking a proline-rich region, a dynamin GTPase effector domain and a pleckstrin homology domain, and may therefore determine the specific functions of the OPA1 protein. Primary structure predictions suggest a high probability of coiled-coil formations in domains encoded by exons 5b-7 (100\%) and exons 27-28 (95\%), and these may be involved in the formation of homodimers or polymers or the binding of as yet unknown cellular partners. OPA1 shows 33\% homology to Mgm1 and 31\% homology to Msp1, both members of a subfamily of dynamins found in Saccharomyces cerevisiae and Schizosaccharomyces pombe where they have been shown to play a role in the maintenance of the mitochondrial genome and mitochondrial morphology. Recent immuno-fluorescence and biochemical evidence suggests that the highly basic amino-terminal extension is essential for OPA1 targeting to mitochondria ${ }^{40,48,49}$ and for mitochondrial inner membrane structure and integrity. ${ }^{50}$

The Bst/ + mouse, which has a variable reduction in the size of the optic nerves, reduced or complete absence of the pupillary light reflex and atrophy of the optic nerves $^{51}$ (and also shows subretinal neovascularization 
with age, ${ }^{52}$ has recently been excluded as a model for ADOA. ${ }^{53}$

\section{Recessive optic atrophy}

Isolated recessive optic atrophy, of which Behr syndrome is an example, may present at birth or soon after ${ }^{54}$ with profound visual deficit, nystagmus, and marked optic nerve pallor. Type III 3-methylglutaconic aciduria (MGA), also known as optic atrophy plus syndrome, or Costeff optic atrophy syndrome, is a recessive neuroophthalmological syndrome that consists of early-onset bilateral optic atrophy and later-onset spasticity, extrapyramidal dysfunction, and cognitive deficit. The OPA3 gene (chromosome 19q13.2-q13.3) has been found to be mutated in patients with MGA. ${ }^{55}$ OPA3 consists of a $5^{\prime} \mathrm{UTR}$ of $150 \mathrm{bp}$, an open reading frame of 179 amino acids, and $>970$ nucleotides of $3^{\prime}$ untranslated sequence. Northern blot analysis demonstrates a primary transcript of approximately $5.0 \mathrm{~kb}$ that is ubiquitously expressed, most prominently in skeletal muscle, kidney, and brain. The protein product is predicted to be a $20-\mathrm{kD}$ peptide, containing a mitochondrial targeting peptide, NRIKE, at amino acid residues 25-29. The protein is predicted, with a probability of 0.87 , to be exported to the mitochondrion, where it may have a significant, but totally unknown, role in mitochondrial processes. This fact is most intriguing in view of the work to date on LHON and the OPA1 protein. Recently, the first locus for isolated autosomal recessive optic atrophy (ROA1), has been mapped to chromosome $8 \mathrm{q} 21-\mathrm{q} 22 .{ }^{56}$

\section{X-linked optic atrophy}

An X-linked inheritance of optic atrophy was first described in $1974^{57,58}$ in a pedigree in which affected males had mental retardation and dysarthria, tremor, dysdiadochokinesia, and abnormal reflexes. Female carriers were normal. The age of onset of optic atrophy was early childhood, no nystagmus was seen, and there was a very slow loss of visual acuity with age. The optic discs showed total pallor and defects in colour vision were reported and visually evoked potentials showed prolonged latencies. A gene for X-linked optic atrophy (OPA2) has been mapped to Xp11.4-p11.2 ${ }^{59}$ in the same pedigree, but so far the gene has not been identified.

\section{Glaucoma}

The glaucomas are a highly heterogeneous group of disorders in which the final common path for visual loss is also retinal ganglion cell death. Retinal ganglion cell death leads to optic nerve head excavation, or glaucomatous cupping, and a corresponding visual field loss. Intraocular pressure may be elevated above $21 \mathrm{mmHg}$, such as in primary open-angle glaucoma (POAG), or within the normal range, such as in normal tension glaucoma (NTG). Primary glaucoma is heterogeneous in both phenotype and in its heritable basis. The onset may be congenital, juvenile or adult, and there may be several different disease mechanisms. The genetic contribution to glaucoma is estimated to be as high as $50-60 \%,{ }^{60}$ although estimates vary. ${ }^{61}$ While there is clearly a significant genetic basis to glaucoma, this could be due to single genes or multiple genes acting with or without environmental factors. ${ }^{2}$ Although rare forms of juvenile glaucoma may be caused by mutations in a single gene, ${ }^{62}$ the majority of cases are likely to have a complex aetiology, with environmental risk factors such as intraocular pressure, age, systemic hypertension, and vasospasm, leading to ganglion cell damage in individuals with a high-risk genotype.

There are currently eight mapped disease loci for nonsyndromic glaucoma (GLC1B 2cen-q13, GLC1C 3q2124, GLC1D 8q23, GLC1F 7q35-36, GLC3B 1p36, PDS1 7q35-36, PDS2 18q11-21, and RIEG2 13q14). Three genes (CYP1B1, ${ }^{62}$ MYOC, $^{63}$ and OPTN ${ }^{64}$ ) have been identified. There are four genes (PAX6, PITX2, FOXC1, and LMX1B) associated with complex glaucoma phenotypes involving anterior segment dysgenesis or ocular developmental anomalies. However, these loci and genes may account for only a small proportion of glaucoma seen in the general population. Studies of MYOC and OPTN mutations in the general glaucoma population have shown that they account for $3.4 \%$ of open angle glaucoma ${ }^{65}$ and up to $15 \%$ of $\mathrm{NTG}^{64}$ respectively. The association of two intronic OPA1 polymorphisms in the OPA1 gene with normal tension glaucoma (IVS8 $+4 \mathrm{C} / \mathrm{T}$ and IVS $8+32 \mathrm{~T} / \mathrm{C}),{ }^{66,67}$ is of interest since NTG may account for $20-50 \%$ of open angle glaucoma. ${ }^{68}$ Normal tension glaucoma and dominant optic atrophy share many overlapping clinical features, ${ }^{69}$ and it may be difficult in some cases to distinguish the conditions by the appearance of the optic nerve. ${ }^{70,71}$ By inference, there may also be a role for mitochondrial dysfunction in NTG, although data are currently lacking to support this hypothesis. Other genes may also play a role in NTG, including the inheritance of the apolipoprotein $\mathrm{E}$ allele $\varepsilon 4$, which appears to be associated with elevated risk of NTG in a Tasmanian population. ${ }^{72}$

\section{Discussion}

The last decade has significantly deepened our understanding of the molecular genetics of inherited optic neuropathies. New data highlight a possible unifying role for mitochondrial dysfunction in inherited optic nerve disease, whether it be morphological or 
physiological. This is being extensively investigated in LHON, and the recent research on ADOA and OPA1, and the suggestion that the OPA 3 and OPTN proteins may also have a mitochondrial link, provides intriguing new insights. Loss of vision in the primary optic neuropathies is by the final common pathway of ganglion cell death, but it is still far from clear why mutations in such ubiquitously expressed proteins should give rise to such a restricted ocular phenotype. We have much to learn about the pathophysiology of this fascinating group of diseases before we can begin to design new therapeutic interventions. However, it is encouraging that there has been a recent increase in interest in mitochondrial targets for drug development, and this may lead to novel treatments in the future.

\section{Acknowledgements}

MV is an MRC Clinician Scientist Fellow. The author has no proprietary interests in the work described.

\section{References}

1 Bristow EA, Griffiths PG, Andrews RM, Johnson MA, Turnbull DM. The distribution of mitochondrial activity in relation to optic nerve structure. Arch Ophthalmol 2002; 120: 791-796.

2 WuDunn D. Genetic basis of glaucoma. Curr Opin Ophthalmol 2002; 13: 55-60.

3 Man PYW, Turnbull DM, Chinnery PF. Leber hereditary optic neuropathy. J Mel Genet 2002; 39: 162-169.

4 Holder GE. The incidence of abnormal pattern electroretinography in optic nerve demyelination. Electroenceph Clin Neurophysiol 1991; 78: 18-26.

5 Giles RE, Blanc H, Cann HM, Wallace DC. Maternal inheritance of human mitochondrial DNA. Proce Nat Acad Sci USA 1980; 77: 6715-6719.

6 Wallace DC. Mitotic segregation of mitochondrial DNAs in human cell hybrids and the expression of chloramphenicol resistance. Som Cell Molec Genet 1986; 12: 41-49.

7 Chinnery PF, Johnson MA, Wardell TM, Singh-Kler R, Hayes C, Brown DT et al. The epidemiology of pathogenic mitochondrial DNA mutations. Ann Neurol 2000; 48: 188-193.

8 Mackey DA, Oostra R, Rosenberg T, Nikoskelainen E, Bronte-Stewart J, Poulton J et al. Primary pathogenic mtDNA mutations in multigeneration pedigrees with Leber Hereditary Optic Neuropathy. Am J Hum Genet 1996; 59: 481-485.

9 Wallace DC, Singh G, Lott MT, Hodge JA, Schurr TJ, Lezza AMS et al. Mitochondrial DNA mutation associated with Leber's hereditary optic neuropathy. Science 1988; 242: $1427-1430$.

10 Howell N, Bindoff LA, McCullough DA, Kubacka I, Poulton J, Mackey D et al. Leber hereditary optic neuropathy: identification of the same mitochondrial ND1 mutation in six pedigress. Am J Hum Genet 1991; 49: 939-950.

11 Johns DR, Neufeld MJ, Park RD. An ND-6 mitochondrial DNA mutation associated with Leber hereditary optic neuropathy. Biochem Biophys Res Commun 1992; 187: 1551-1557.

12 Mackey D, Howell N. A variant of Leber hereditary optic neuropathy characterized by recovery of vision and by an unusual mitochondrial genetic etiology. Am J Hum Genet 1992; 51: 1218-1228.

13 Howell N, Halvorsen S, Burns J, McCullough DA, Paulton J. When does bilateral optic atrophy become Leber hereditary optic neuropathy? Am J Hum Genet 1993; 53: 959-963.

14 Jun AS, Brown MD, Wallace DC. A mitochondrial DNA mutation at np14459 of the ND6 gene associated with maternally inherited Leber's hereditary optic neuropathy and dystonia. Proc Nat Acad Sci 1994; 91: 6206-6210.

15 Wissinger B, Besch D, Baumann B, Fauser S, Christ-Adler $M$, Jurklies B et al. Mutation analysis of the ND6 gene in patients with Lebers hereditary optic neuropathy. Biochem Biophys Res Commun 1997; 234: 511-515.

16 Huoponen K, Lamminen T, Juvonen V, Aula P, Nikoskelainen E, Savontaus ML. The spectrum of mitochondrial DNA mutations in families with Leber hereditary optic neuroretinopathy. Hum Genet 1993; 92 : 379-384.

17 Johns DR, Neufeld MJ. Cytochrome b mutations in Leber hereditary optic neuropathy. Biochem Biophys Res Commun 1991; 181: 1358-1364.

18 Johns DR, Neufeld MJ. Cytochrome $c$ oxidase mutations in Leber hereditary optic neuropathy. Biochem Biophys Res Commun 1993; 196: 810-815.

19 Howell N, Kubacka I, Halvorson S, Howell B, McCullough DA, Mackey D. Phylogenetic analysis of the mitochondrial genomes from Leber hereditary optic neuropathy pedigrees. Genetics 1995; 140: 285-302.

20 Newman NJ, Lott MT, Wallace DC. The clinical characteristics of pedigrees of Leber's hereditary optic neuropathy with the 11778 mutation. Am J Ophthalmol 1991; 111: $750-762$.

$21 \mathrm{Bu}$ X, Rotter JI. X-chromosome linked and mitochondrial gene control of Leber's hereditary optic neuropathy: evidence from segregation analysis for dependence on $\mathrm{X}$ chromosome inactivation. Proc Nat Acad Sci, USA 1991; 88: 8198-8202.

22 Juvonen V, Vilkki J, Aula P, Nikoskelainen E, Savontaus ML. Reevaluation of the linkage of an optic atrophy susceptibility gene to X-chromosomal markers in Finnish families with Leber hereditary optic neuropathy (LHON). Am J Hum Genet 1993; 53: 289-292.

23 Howell N, Miller NR, Mackey DA, Arnold A, Herrnstadt C, Williams IM et al. Lightning strikes twice: Leber hereditary optic neuropathy families with two pathogenic mtDNA mutations. J Neuroophthalmol 2002; 22: 262-269.

24 Johns DR, Heher KL, Miller NR, Smith KH. Leber's hereditary optic neuropathy. Clinical manifestations of the 14484 mutation: Arch Ophthalmol 1993; 111:495-498.

25 Oostra RJ, Bolhuis PA, Wijburg FA, Zorn-Ende G, BleekerWagemakers EM. Leber's hereditary optic neuropathy: correlations between mitochondrial genotype and visual outcome. J Med Genet 1994; 31: 280-286.

26 Riordan-Eva P, Sanders MD, Govan GG, Sweeney MG, Costa JD, Harding AE. The clinical features of Leber's hereditary optic neuropathy defined by the presence of a pathogenic mitochondrial DNA mutation. Brain 1995; 118: 319-337.

27 Riordan-Eva P, Harding AE. Leber's hereditary optic neuropathy: the clinical relevance of different mitochondrial DNA mutations. J Med Genet 1995; 32: 81-87. 
28 Chinnery PF, Andrews RM, Turnbull DM, Howell N. Leber hereditary optic neuropathy: does heteroplasmy influence the inheritance and expression of the G11778A mitochondrial DNA mutation? Am J Med Genet 2001; 98: 235-243.

29 Carelli V, Ross-Cisneros FN, Sadun AA. Optic nerve degeneration and mitochondrial dysfunction: genetic and acquired optic neuropathies. Neurochem Int 2002; 40: 573-584.

30 Sadun AA, Win PH, Ross-Cisneros FN, Walker S, Carelli V. Leber's hereditary optic neuropathy differentially affects smaller axons in the optic nerve. Trans Am Ophthalmol Soc 2000; 98: 223-232.

31 Howell N. Leber hereditary optic neuropathy: mitochondrial mutations and degeneration of the optic nerve. Vision Res 1997; 37: 3495-3507.

32 Brown MD, Trounce IA, Jun AS, Allen JC, Wallace DC. Functional analysis of lymphoblast and cybrid mitochondria containing the 3460, 11778 or 14484 Leber's hereditary optic neuropathy mitochondrial DNA mutation. J Biol Chem 2000; 275: 39831-39836.

33 Lodi R, Taylor DJ, Tabrizi SJ, Kumar S, Sweeney M, Wood NW et al. In vivo skeletal muscle mitochondrial function in Leber's hereditary optic neuropathy assessed by 31P magnetic resonance spectroscopy. Ann Neurol 1997; 42: 573-579.

34 Lodi R, carelli V, Cortelli P, Iotti S, Valentino ML, Barboni P et al. Phosphorous MR spectroscopy shows a tissue specific in vivo distribution of biochemical expression of the G3460A mutation in Leber's hereditary optic neuropathy. J Neurol, Neurosurg and Psychiatry 2002; 72: 805-807.

35 Wong A, Cavelier L, Collins-Schramm HE, Seldin MF, McGrogan M, Savontaus ML et al. Differentiation-specific effects of LHON mutations introduced into neural cells. Hum Mol Genet 2002; 11: 431-438.

36 Eiberg H, Kjer B, Kjer P, Rosenberg T. Dominant optic atrophy (OPA1) mapped to chromosome $3 q$ region. I. Linkage analysis. Hum Mol Genet 1994; 3: 977-980.

37 Alexander C, Votruba M, Pesch U, Thiselton D, Mayer S, Moore A et al. OPA1, encoding a dynamin-related GTPase, is mutated in autosomal dominant optic atrophy linked to chromosome 3q28. Nature Genet 2000; 26 : 211-215.

38 Delettre C, Lenaers G, Griffoin J, Gigarel N, Lorenzo C, Belenguer $\mathrm{P}$ et al. Nuclear gene OPA1, encoding a mitochondrial dynamin-related protein, is mutated in dominant optic atrophy. Nature Genet 2000; 26: 207-210.

39 Kerrison JB, Arnould VJ, Sallum JMF, Vagefi MR, Barmada MM, Li YY et al. Genetic heterogenity of dominant optic atrophy, Kjer type - Identification of a second locus on chromosome 18q12.2-12.3. Arch Ophthalmol 1999; 117: 805-810.

40 Misaka T, Miyashita T, Kubo Y. Primary structure of a dynamin-related mouse mitochondrial GTPase and its distribution in brain, subcellular localization and effect on mitochondrial morphology. J Biol Chem 2002; 277: 15834-15842.

41 Delettre C, Griffoin J-M, Kaplan J, Dollfus H, Lorenz B, Faivre $\mathrm{L}$ et al. Mutation spectrum and splicing variants in the OPA1 gene. Hum Genet 2001; 109: 584-591.

42 Toomes C, Marchbank NJ, Mackey DA, Craig JE, NewburyEcob RA, Bennett CP et al. Spectrum, frequency and penetrance of OPA1 mutations in dominant optic atrophy. Hum Mol Genet 2001; 10: 1369-1378.
43 Pesch AEA, Leo-Kottler B, Mayer S, Jurklies B, Kellner U, Apfelstedt-Sylla E et al. OPA1 mutations in patients with autosomal dominant optic atrophy and evidence for semi-dominant inheritance. Hum Mol Genet 2001; 10: 1359-1368.

44 Thiselton DL, Alexander C, Morris A, Brooks S, Rosenberg $\mathrm{T}$, Eiberg $\mathrm{H}$ et al. A frameshift mutation in exon 28 of the OPA1 gene explains the high prevalence of dominant optic atroophy in the Danish population: evidence for a founder effect. Hum Genet 2001; 109: 498-502.

45 Shimizu S, Mori N, Kishi M, Sugata H, Tsudo A, Kubota N. A novel mutation of the OPA1 gene in a Japanese family with optic atrophy type I. Jpn J Ophthalmol 2002; 46: 336-340.

46 Thiselton DL, Alexander C, Taanman J-W, Brooks S, Rosenberg T, Eiberg $\mathrm{H}$ et al. A comprehensive survey of mutations in the OPA1 gene in patients with autosomal dominant optic atrophy (ADOA). Invest Ophthalmol Visual Sci 2002; 43: 1715-1724.

47 Marchbank NJ, Craig JE, Leek JP, Toohey M, Churchill AJ, Markham AF et al. Deletion of the OPA1 gene in a dominant optic atrophy family: evidence that haploinsufficiency is the cause of disease. J Med Genet 2002; 39: e47.

48 Olichon A, Emorine LJ, Descoins E, Pelloquin L, Brichese L, Gas $\mathrm{N}$ et al. The human dynamin-related protein OPA1 is anchored to the mitochondrial inner membrane facing the inter-membrane space. FEBS Lett 2002; 523: 171-176.

49 Satoh M, Hamamoto T, Seo N, Kagawa Y, Endo H. Differential sublocalization of the dynamin-related protein OPA1 isoforms in mitochondria. Biochem Biophys Res Commun 2002; 300: 482-493.

50 Olichon A, Baricault L, Gas N, Guillou E, Valette A, Belenguer $\mathrm{P}$ et al. Loss of OPA1 pertubates the mitochondrial inner membrane structure and integrity, leading to cytochrome c release and apoptosis. J Biol Chem 2003; 7: 7743-7746.

51 Rice DS, Tang Q, Williams RW, Harris BS, Davisson MT, Goldowitz D. Decreased retinal ganglion cell number and misdirected axon growth associated with fissure defects in Bst / + mutant mice. Invest Ophthalmol and Visual Sci 1997; 38: 2112-2124.

52 Smith RS, John SW, Zabeleta A, Davisson MT, Hawes NL, Chang B. The bst locus on mouse chromosome 16 is associated with age-related subretinal neovascularisation. Proc Nat Acad Sci USA 2000; 29: 2191-2195.

53 Delettre C, Lenaers G, Belenguer P, Hamel CP. Gene structure and chromosomal localization of mouse Opa1: its exclusion from the Bst locus. BMC Genet 2003; 4: 8 .

54 Waardenburg PJ. Different types of hereditary optic atrophy. Acta Genet Statist Med 1957; 7: 287-290.

55 Anikster Y, Kleta R, Shaag A, Gahl WA, Elpeleg O. Type III 3-methylglutaconic aciduria (Optic Atrophy Plus Syndrome, or Costeff Optic Atrophy Syndrome): identification of the OPA3 gene and its founder mutation in Iraqi Jews. Am J Hum Genet 2001; 69: 1218-1224.

56 Barbet F, Gerber S, Hakiki S, Perrault I, Hanein S, Ducroq D et al. A first locus for isolated autosomal recessive optic atrophy (ROA1) maps to chromosome 8q. Eur J Hum Genet 2003; advance online publication doi:10.1038/ sj.ejhg.5201070.

57 Volker-Dieben HJ, Lith GHMV, Went LN, Klawer JW, Staal A, Mol ECDV-d. A family with sex linked optic atrophy (ophthalmological and neurological aspects). Documenta Ophthalmol 1974; 37: 307-326. 
58 Went LN, Mol ECDV-d, Volker-Dieben HJ. A family with apparently sex-linked optic atrophy. J Med Genet 1975; 12: 94-98.

59 Assink JJM, Tijmes NT, tenBrink JB, Oostra R, Riemslag FC, deJong PTVM et al. A gene for X-linked optic atrophy is closely linked to the Xp11.4-Xp11.2 region of the $\mathrm{X}$ chromosome. Am J Hum Genet 1997; 61: 934-939.

60 McNaught AI, Allen JG, Healey DL, McCartney PJ, Coote MA, Wong TL et al. Accuracy and implications of a reported family history of glaucoma: experience from the Glaucoma Inheritance Study in Tasmania. Arch Ophthalmol 2000; 118: 900-904.

61 Wolfs RC, Klaver CC, Ramrattan RS, vanDuijn CM, Hofman A, deJong PT. Genetic risk of primary open angle glaucoma. Arch Ophthalmol 1998; 116: 1640-1645.

62 Stoilov I, Akarsu AN, Sarfarazi M. Identification of three truncating mutations in cytochrome P4501B1 (CYP1B1) as the principal cause of primary congenital glaucoma (buphthalmos) in families linked to the GLC3A locus on chromosome 2p21. Hum Mol Genet 1997; 6: 641-647.

63 Stone EM, Figert JH, Alward WLM, Nguyen TD, Polansky JR, Sunden SLF et al. Identification of a gene that causes primary open angle glaucoma. Science 1997; 275: 668-670.

64 Rezaie T, Child A, Hitchings R, Brice G, Miller L, Coca-Prados $\mathrm{M}$ et al. Adult-onset primary open-angle glaucoma caused by mutations in optineurin. Science 2002; 295: 1077-1079.

65 Fingert JH, Heon E, Liemann JM, Yamamoto T, Craig JE, Rait J et al. Analysis of myocilin mutations in 1703 glaucoma patients from five different populations. Hum Mol Genet 1999; 8: 899-905.

66 Aung T, Ocaka L, Ebeneezer N, Morris A, Krawczak M, Thiselton DL et al. A major marker for normal tension glaucoma: association with polymorphisms in the OPA1 gene. Hum Genet 2002; 110: 52-56.

67 Aung T, Ocaka L, Ebenezer ND, Morris AG, Brice G, Child $\mathrm{AH}$ et al. Investigating the association between OPA1 polymorphisms and glaucoma: comparison between normal tension and high tension primary open angle glaucoma. Hum Genet 2002; 110: 513-514.

68 Kamal D, Hitchings R. Normal tension glaucoma-a practical approach. Br J Ophthalmol 1998; 82: 835-840.

69 Buono LM, Foroozan R, Sergott RC, Savino PJ. Is normal tension glaucoma actually an unrecognised hereditary optic neuropathy? New evidence from genetic analysis. Curr Opin Ophthalmol 2002; 13: 362-370.

70 Fournier AV, Damj KF, Epstein DL, Pollock SC. Disc excavation in dominant optic atrophy: differentiation from normal tension glaucoma. Ophthalmology 2001; 108 : 1595-1602.

71 Votruba M, Thiselton D, Bhattacharya S. Optic disc morphology of patients with OPA1 autosomal dominant optic atrophy. $\mathrm{Br}$ J Ophthalmol 2003; 87: 48-53.

72 Vickers JC, Craig JE, Stankovich J, McCormack GH, West AK, Dickson JL et al. The apolipoprotein e4 gene is associated with elevated risk of normal tension glaucoma. Mol Vision 2002; 8: 389-393. 